\title{
Eeonomie
}

Central European Review of Economics \& Finance

Vol. 27, No. 5(2018), pp. 5-26

DOI: $10.24136 /$ ceref.2018.023

Received: 27 August 2018. Accepted: 10 October 2018.

Viktória VÁSÁRY ${ }^{1}$, Dorottya SZABÓ ${ }^{2}$

\section{CHARACTERISTICS OF SUSTAINABLE BIOECONOMY IN THE CEE MACRO-REGION}

In the coming decades to achieve further progress in sustainable growth of agriculture, aquaculture, forestry and food industry in the CEE countries there is a need to face specific challenges through the lens of bioeconomy, thus by shifting the emphasis to research, innovation and transnational cooperation for knowledge-based development. A shared strategic research and innovation framework that has already been offered by the Central-Eastern European Initiative for Knowledge-based Agriculture, Aquaculture and Forestry in the Bioeconomy, i.e. by the BIOEAST Initiative might enable these countries to work towards the development of a sustainable bioeconomy while effectively joining the European Research Area. The study is aimed at conceptualizing bioeconomy, analysing key socio-economic indicators of the 'BIOEAST countries' bioeconomy and describing the implications for policymakers based on the results of the 'BIOEAST Bioeconomy Capacity Building Survey'.

Based on the results of the survey the major findings of the research verify and strengthen the objectives of the BIOEAST Initiative. The individual results of the survey in terms of major bottlenecks in the supply chain, missing elements hindering competitiveness, the opportunities to raise competitiveness and functions of the intervention system led to the conclusion that the creation of sustainable bioeconomy explicitly requires triple-helix stakeholders to find efficient collaboration mechanisms and build synergies.

Keywords: bioeconomy, circular economy, sustainability, research and innovation.

JEL Classification Codes: 013, O3, Q16, Q58.

\footnotetext{
${ }^{1}$ Scientific advisor, Research Institute of Agricultural Economics, Budapest, Hungary.

${ }^{2}$ Research fellow, Research Institute of Agricultural Economics, Budapest, Hungary.
} 


\section{Introduction}

Over the last ten years the resources of the Common Agricultural Policy have helped the Central and Eastern European (CEE) regions of the European Union (EU) to improve their agri-food sectors, environment and rural areas, thus increasing economic and social cohesion. In the coming decades, however, to achieve further progress in sustainable growth of agriculture, aquaculture, forestry and food industry there is a need to face specific challenges arising from climate change in the Continental Biogeographical Region, and the common societal and governance issues of the CEE countries through the lens of bioeconomy, thus by shifting the emphasis to research, innovation and transnational cooperation for knowledge-based development. As the European Union sees significant internal disparities in terms of research and innovation performance - as also identified in the Innovation Union Scoreboard - to the disadvantage of the CEE countries, they are hindered in effectively joining the European Research Area. Accordingly, considerable efforts are required to address present and future challenges successfully and to undertake these efforts efficiently a suitable framework is necessary. This framework ought to be a shared strategic research and innovation framework for working towards the development of a sustainable bioeconomy in the CEE countries. The framework itself has already been offered by the Central-Eastern European Initiative for Knowledge-based Agriculture, Aquaculture and Forestry in the Bioeconomy, i.e. by the BIOEAST Initiative.

The BIOEAST Initiative is an open initiative started by the Visegrad Group Countries - Czech Republic, Hungary, Poland, Slovakia - and joined by Bulgaria, Romania, Slovenia, Croatia and Estonia. (Additional details are to be found on the BIOEAST website: http://www.bioeast.eu/) It is aimed at bridging the gap in terms of research and innovation between western EU member states and the CEE macro-region and could serve as the thematic framework of a Coordination Support Action. Furthermore, it is capable of supporting and strengthening the conceptual framework of the circular bioeconomy. (BIOEAST, 2018)

The study is aimed at conceptualizing bioeconomy, analysing key socio-economic indicators of the 'BIOEAST countries' bioeconomy and describing the implications for policymakers based on the results of the 'BIOEAST Bioeconomy Capacity Building Survey'.

\section{Methodology}

Both primary and secondary research has been carried out. The latter included review of relevant international literature and documents on circular economy and bioeconomy and the primary research focused on statistical analysis of data gathered in a survey. The 'BIOEAST Bioeconomy Capacity Building Survey' was adopted in the framework of 
the BIOEAST Initiative from the Survey jointly elaborated during the Danube-INCO.NET project by the Central European Initiative and PANNON Pro Innovations and was hosted online (on the website of the Hungarian Research Institute of Agricultural Economics) for three months in Summer 2017. The survey intended to spotlight the main challenges of the development of bioeconomy in the Visegrad Countries, Bulgaria, Romania, Slovenia and Croatia ${ }^{3}$ by mapping knowledge and capacities, furthermore, through the collection of the views and suggestions of the respondents on how to minimize bottlenecks. It was designed specifically for respondents from the public sector, research and academia, as well as businesses that are active along the biomass value chain and was divided into 4 sections. The aim of the "Capacity mapping" section was to better understand the activities of the companies, institutes and government agencies and their potential for advanced bio-based products. In Section II the focus was set on the bottlenecks preventing the production of advanced biobased materials and fuels which are produced from biomass sources not competing with current patterns of food and feed production and mostly considered as waste or by-product. In Section III we intended to learn about what stakeholders think the most beneficial for CEE macro region in developing bioeconomy. The last section was aimed at the identification of wished interventions.

The respondents were chosen randomly through personal contacts of experts working in the Hungarian Research Institute of Agriculture, Ministry of Agriculture and the Chamber of Agriculture (they created a judgement sample) and by snowball sampling to get further contacts from respondents. The questionnaire was sent to a small subset of the target groups and the answers were examined through descriptive and inferential statistical analysis.

\section{Theoretical background}

The literature review on circular economy (CE) and bioeconomy proves that it is a difficult task to provide conceptual clarity and to recognize relationships between these terms plus the concept of sustainability, a term often used together with CE and bioeconomy. Definitions and analysis of features of these concepts are published by several authors such as - not aiming to be exhaustive - Kovács et. al., 2015; Kirchherr et al., 2017; Geissdoerfer et al., 2017; Ellen Macarthur Foundation, (describing and analysing CE); Aguilar et al., 2018; Bell et al., 2018; D'Amato et al., 2017; Dupont-Inglis et al., 2018; Efken et al., 2016; Golden et al., 2018; Patermanna et al., 2018; Philp, 2018; Ronzon et al., 2017; Ronzon et al., 2018; Scarlat et al., 2015; Bugge et al., 2016; Pavone et al., 2017; Lewandowski, 2017; Filho et al., 2018; Schütte, 2018; Thorenz et al., 2018; Wozniak et al., 2018 (describing and analysing bioeconomy) Besides scientific papers

\footnotetext{
${ }^{3}$ In this study these countries are analysed, and they are called BIOEAST countries.
} 
several policy documents, law proposals have been published, among others by the European Commission (EC) ${ }^{4}$ or the $\mathrm{OECD}{ }^{5}$. The research findings and the policy papers are considered widely spread and available (lots of them are open access) thus the authors do not go into general details, do not list the stages of the evolution of these research fields, they only intend to stress that similarities and differences among the abovementioned concepts are still ambiguous and name their preference for definitions.

Concerning CE one of the most comprehensive definitions is the one created by Kirchherr and his colleagues. Circular economy is an „economic system that replaces the 'end-of-life' concept with reducing, alternatively reusing, recycling and recovering materials in production/distribution and consumption processes. It operates at the micro level (products, companies, consumers), meso level (eco-industrial parks) and macro level (city, region, nation and beyond), with the aim to accomplish sustainable development, thus simultaneously creating environmental quality, economic prosperity and social equity, to the benefit of current and future generations. It is enabled by novel business models and responsible consumers". (Kirchherr et al., 2017) Concerning bioeconomy we use the definition of the European Commission: "The bioeconomy encompasses the production of renewable biological resources and the conversion of these resources and waste streams into value added products, such as food, feed, biobased products and bioenergy". (EC, 2017:31) At the same time we draw the attention to the article written by Bugge et. al. who identified three visions - the bio-technology, the bio-resource and the bio-ecology vision of bioeconomy. (Bugge et al., 2016: 9) Key characteristics of these visions are listed in Table 1.

The term 'sustainable bioeconomy' has been introduced as well. The 4th SCAR foresight exercise by the European Commission used it and described its key principles: food first approach, sustainable yields, cascading approach and circularity. (See Kovács et al., 2015 for details).

Although the concept of circular economy and bioeconomy are different, they complement each other as both intend to improve resource and eco-efficiency, create low GHG footprint, reduce the demand for fossil carbon and enhance waste and side streams. Thus, at the intersection of bioeconomy and circular economy (see Figure 1.) there is 'Circular Bioeconomy'. (EC, 2017).

\footnotetext{
${ }^{4}$ For further details see the websites of the EC on circular economy (http://ec.europa.eu/environment/circular-economy/index_en.htm; https://ec.europa.eu/commission/publications/european-commission-proposalscircular-economy_en) and on bioeconomy. https://ec.europa.eu/research/bioeconomy/index.cfm?pg=library, see.e.g. EC, 2012; EC, 2013; EC, 2014; EC, 2017; Spatial Foresight, SWECO, ÖIR, t33, Nordregio, Berman Group, Infyde, 2017

${ }^{5}$ e.g. McCarthy et al., 2018; OECD, 2009; OECD, 2018; Website of Bio-based economy (http://www.oecd. org/sti/biotech/bio-basedeconomy.htm)
} 
Table 1. Key characteristics of the bioeconomy visions.

\begin{tabular}{|c|c|c|c|}
\hline & The Bio-Technology Vision & The Bio-Resource Vision & The Bio-Ecology Vision \\
\hline $\begin{array}{l}\text { Aims \& } \\
\text { objectives }\end{array}$ & $\begin{array}{l}\text { Economic } \\
\text { growth \& job creation }\end{array}$ & $\begin{array}{l}\text { Economic } \\
\text { growth \& sustainability }\end{array}$ & $\begin{array}{l}\text { Sustainability, biodiversity, con- } \\
\text { servation of ecosystems, avoid- } \\
\text { ing soil degradation }\end{array}$ \\
\hline Value creation & $\begin{array}{l}\text { Application of biotechnology, } \\
\text { commercialisation } \\
\text { of research \& technology }\end{array}$ & $\begin{array}{l}\text { Conversion and upgrading } \\
\text { of bio-resources } \\
\text { (process oriented) }\end{array}$ & $\begin{array}{l}\text { Development of integrated pro- } \\
\text { duction systems and high-quality } \\
\text { products with territorial identity }\end{array}$ \\
\hline $\begin{array}{l}\text { Drivers \& } \\
\text { mediators } \\
\text { of innovation }\end{array}$ & $\begin{array}{l}\text { R \& D, patents, TTOs, Re- } \\
\text { search councils and funders } \\
\text { (Science push, linear model) }\end{array}$ & $\begin{array}{l}\text { Interdisciplinary, optimisation } \\
\text { of land use, include degrad- } \\
\text { ed land in the production of } \\
\text { biofuels, use and availability } \\
\text { of bio-resources, waste man- } \\
\text { agement, engineering, sci- } \\
\text { ence \& market (Interactive \& } \\
\text { networked production mode) }\end{array}$ & $\begin{array}{l}\text { Identification of favourable or- } \\
\text { ganic agro-ecological practices, } \\
\text { ethics, risk, transdisciplinary } \\
\text { sustainability, ecological inter- } \\
\text { actions, re-use \& recycling of } \\
\text { waste, land use, (Circular and } \\
\text { self-sustained production mode) }\end{array}$ \\
\hline Spatial focus & Global clusters/Central regions & Rural/Peripheral regions & Rural/Peripheral regions \\
\hline
\end{tabular}

Source: Bugge et al., 2016

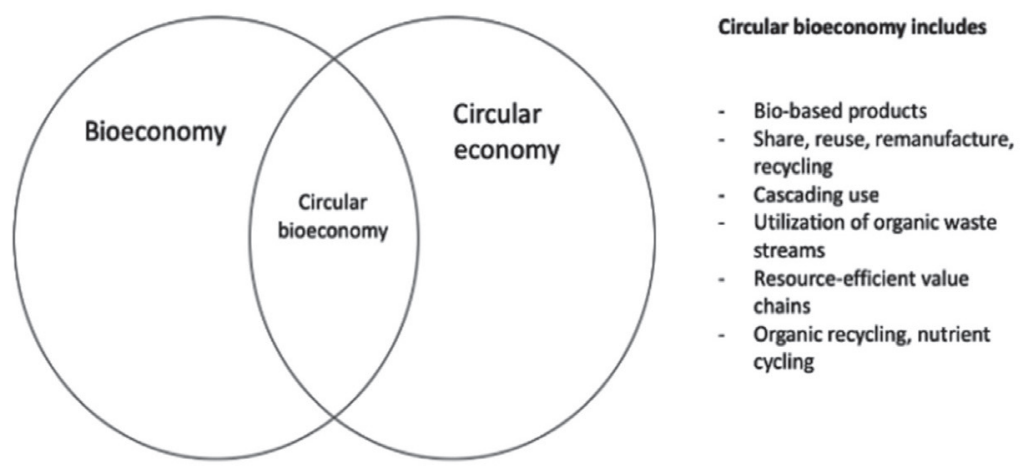

Figure 1. Circular bioeconomy

Source: EC, 2017.

\section{Bioeconomy in the BIOEAST countries}

As regards the bioeconomy's importance in the EU there is a state of the art study published by Ronzon et al. in 2018 who made a state of play assessment by using data compiled in the JRC Bioeconomics dataset ${ }^{6}$. The assessment is considered a complex

\footnotetext{
${ }^{6}$ Bulk download is available at https://datam.jrc.ec.europa.eu/datam/perm/od/jrc-datam-biomass-estimates/ download; infographics is available at https://datam.jrc.ec.europa.eu/datam/mashup/BIOECONOMICS
} 
task as according to the official statistical classification of economic activities of the European Community (NACE rev. 2.) the economic activities are not divided into bio-based or non-bio-based activities. Thus, certain sectors include both. In case of these socalled 'hybrid' sectors' it is a major requirement to measure the extent to which a given hybrid sector is bio-based. The methodology to quantify the sectoral bio-based shares is described by Ronzon and his colleagues. (Ronson et al., 2018) As a result, this study covers key socioeconomic indicators, clustering of EU member states and heat map of the sectoral contribution to bioeconomy jobs and value added. In a nutshell the following can be summarized: The EU-28 bioeconomy employed 18 million people ( $8.2 \%$ of the labour force) and generated 2.3 trillion of turnover or 620 million of value added $(4.2 \%$ of the EU-28 GDP) in 2015. About two thirds of the value added and turnover of the bioeconomy and three quarters of bioeconomy employment are generated by agriculture and the manufacture of food, beverages and tobacco. Sectoral contributions vary, however, according to the degree of labour intensiveness of the sector. Using some socioeconomic indicators, the authors proposed a typology based on the concentration of national labour markets into the bioeconomy (as a proxy for the employment situation) and apparent labour productivity of the bioeconomy (as an indicator reflecting economic growth potential) and created 4 groups - Group 1 'Eastern Member States, Portugal and Greece', Group 2 'Baltic and Central Member States', Group 3 'Western Member further States', and Group 4 'Northern Member States' (further details see Ronzon et al, 2018, p. 7-15)

The BIOEAST countries which are in the focus of this study belong to the first and second group. (Table 2) Bulgaria, Croatia, Poland and Romania are part of the first group defined by a strong specialisation of national labour markets in the bioeconomy and a level of apparent labour productivity of the bioeconomy below half the EU-28 level and the Czech Republic, Hungary, Slovakia and Slovenia are part of the second group defined by a medium specialisation of national labour markets in the bioeconomy on the EU-28 scale and a level of apparent labour productivity of the bioeconomy of between half the EU-28 level and the EU-28 average level. (Ronzon et al.2018).

\footnotetext{
${ }^{7}$ Agriculture (A02 Forestry, A03 Fishing and aquaculture, A032 Aquaculture, A031 Fishing); Manufacture of food, beverages and tobacco (C10 Manufacture of food, C11 Manufacture of beverages, $\mathrm{C} 12$ Manufacture of tobacco); Manufacture of bio-based textiles (C13 * Manufacture of bio-based textiles, $\mathrm{C} 14$ * Manufacture of bio-based wearing apparel, C15 Manufacture of leather); Manufacture of wood products and furniture (C16 Manufacture of wood products, C31 * Manufacture of wooden furniture, C17 Manufacture of paper); Manufacture of bio-based chemicals, pharmaceuticals, plastics and rubber (excluding biofuels) (C20 * Manufacture of bio-based chemicals (excluding biofuels), C21 * Manufacture of bio-based pharmaceuticals, C22 * Manufacture of bio-based plastics and rubber); Manufacture of liquid biofuels (C2014 * Manufacture of bioethanol, C2059 * Manufacture of biodiesel, D3511 * Production of bioelectricity) - *hybrid sector (Ronzon et al., 2018).
} 


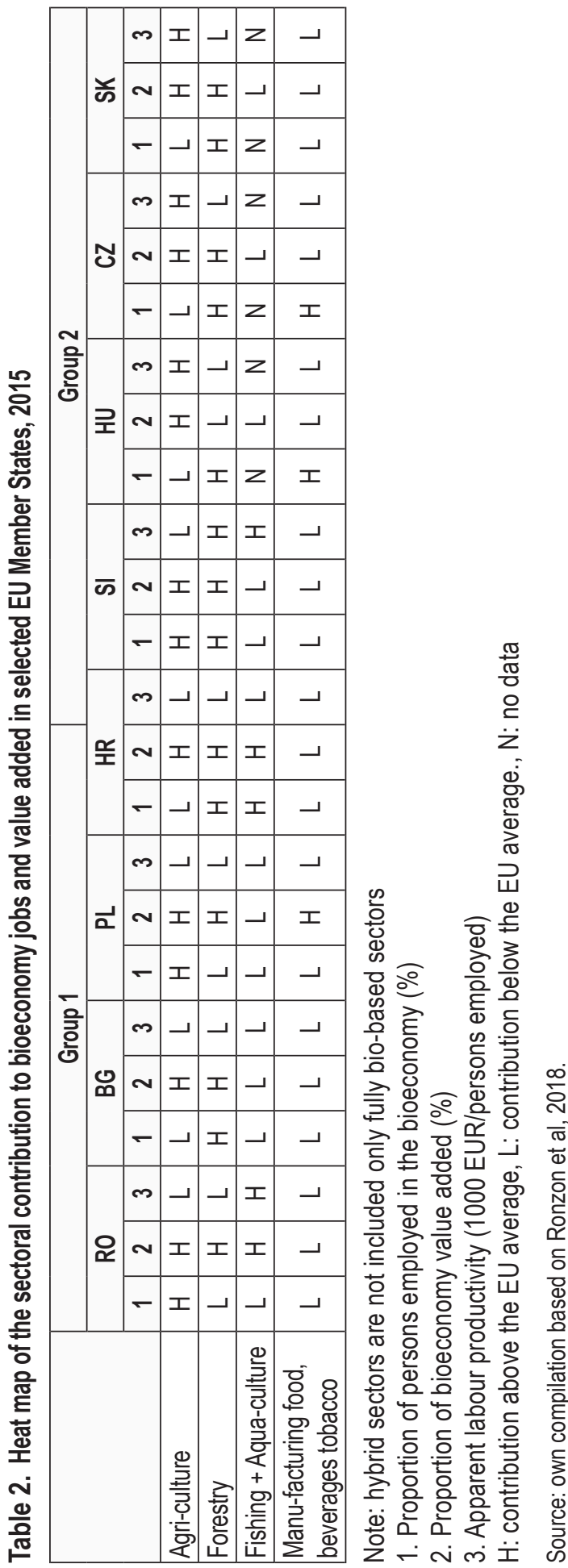


In the period between 2008 and 2015 there was a decreasing trend in the number of people employed in agriculture; forestry; fishing and aquaculture; food, beverages, tobacco (Figure 2) in the BIOEAST countries.

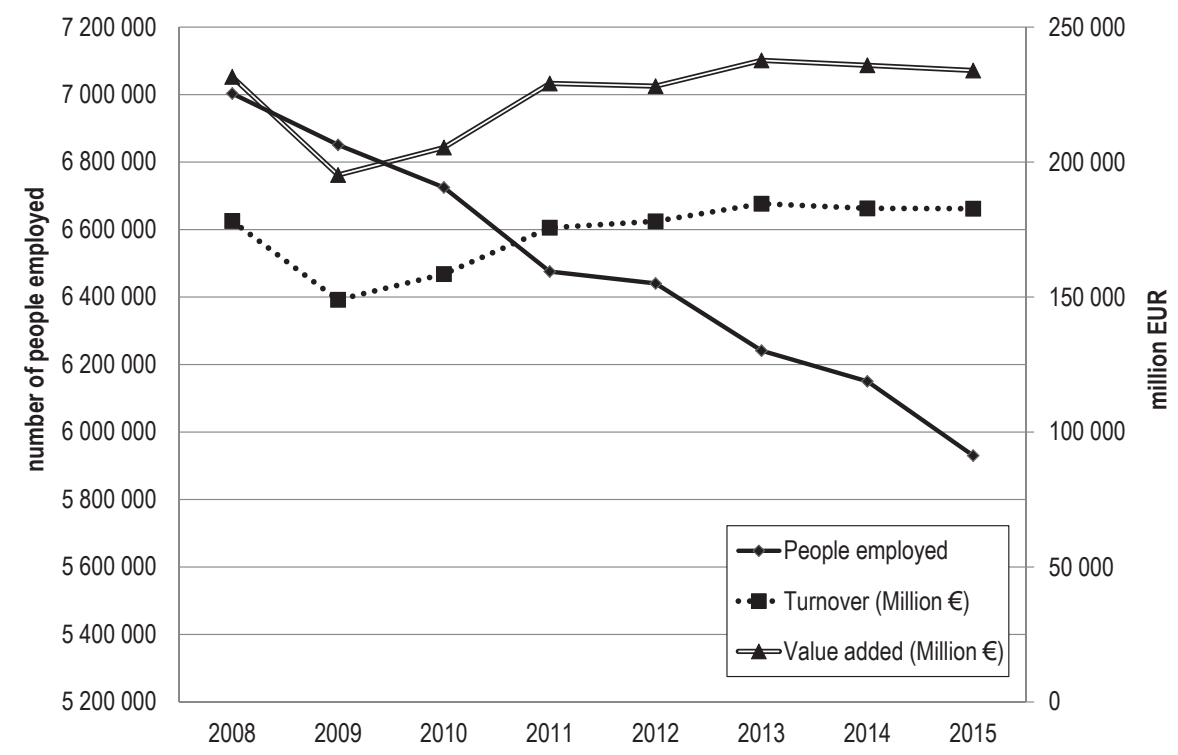

Figure 2. Development of jobs, turnovers, value added in selected sectors - agriculture, forestry, fishing and aquaculture, food, beverages and tobacco - of the bioeconomy in the BlOEAST countries

Source: own composition based on JRC Bioeconomics dataset.

As regards turnover and value added generated by these sectors there was a decline in both from 2008 to 2009 due to the global financial and economic crisis, followed by a recovery. In 2012 the level of turnover reached the level measured in 2008, and in 2013 the level of value added came close to the level measured in 2008. (Further details see Annex 1 and 2).

The apparent labour productivity (calculated by using the JRC Bioeconomics dataset) increased from 2008 to 2015 in almost all countries and sectors analysed. The degree of improvement is, however, different among the countries. The sectoral levels of apparent labour productivity show very wide ranges of variation at the level of the BIOEAST countries. (For details see Figure 3). 


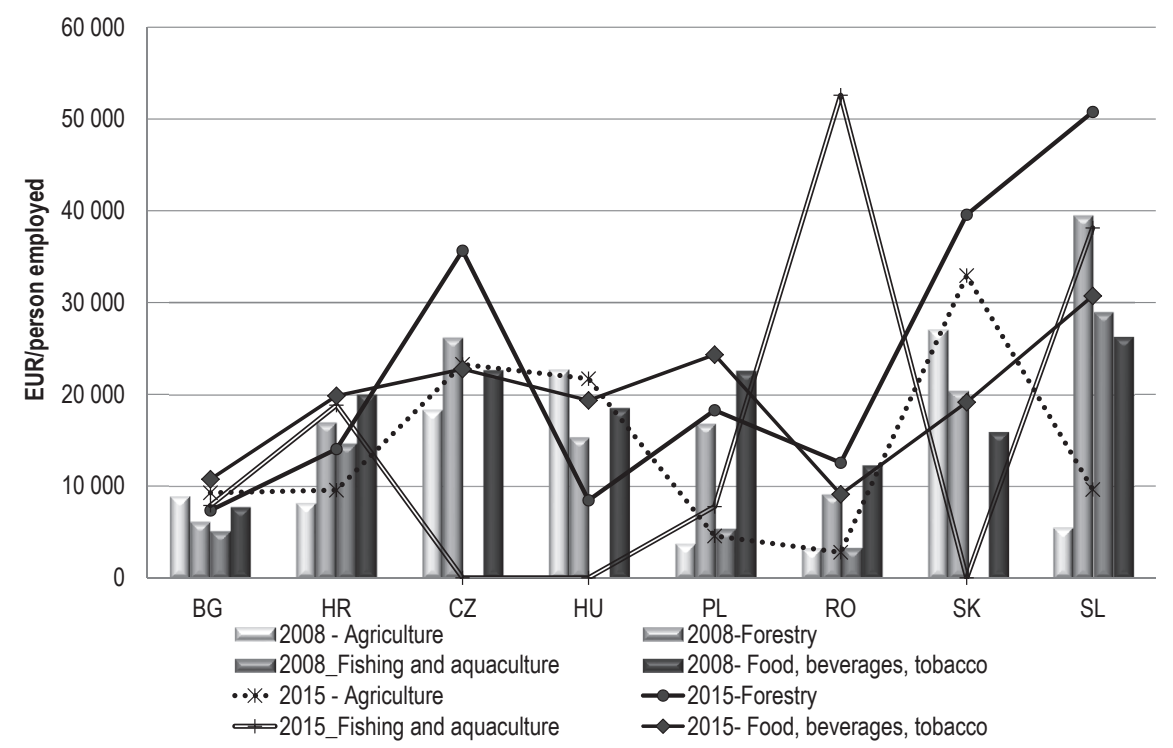

Figure 3. Apparent labour productivity in the BIOEAST countries

Note: There is no available data on labour force working in the fishing and aquaculture sector in $\mathrm{CZ}$, $\mathrm{HU}$ and SK, thus apparent labour productivity cannot be calculated.

Source: own calculation and composition based on JRC Bioeconomics dataset.

\section{Results of the BIOEAST survey}

Regarding respondent demographic, out of 141 complete responses there were 24 (17\%) given by stakeholders of businesses, industry or SMEs/start-ups, 80 (56.7\%) by academic or research sector and $37(26.2 \%)$ by public sector or NGO stakeholders. A greater number of responses were received from Hungary, Czech Republic, Bulgaria and Romania. The total number of respondents and relative proportions of stakeholder groups are listed in Table 3.

Most companies operate in the energy (45\%), agriculture (37\%) and environmental protection $(29 \%)$ sectors. The academic activities of the respondents are principally related to agriculture (30\%), environmental studies $15 \%$ and bio-sciences (14\%). The majority of the third stakeholder group is employed by Governmental Agencies or Bodies $(32 \%)$ and NGOs $(29 \%)$.

The majority of business activities of the 'Business' sector's respondents are related to biomass production (37\%), R\&D service and consulting (37\%) and biomass conversion $(29 \%)$. Their activities focus primarily on animal feed $(25 \%)$, food products (17\%), advanced bio-based materials: chemicals, pharmaceuticals (12.5\%), advanced liquid biofuels $(12.5 \%)$ and liquid biofuels $(12.5 \%)$. The biomass production activity focuses 
mainly on forestry products and energy crops. Among the R\&D and consulting activities there are the knowledge transfer $(29 \%)$, the process design (29\%) and the education and training (25\%) to mention.

Table 3. Responses to BIOEAST Survey by stakeholder group and region

\begin{tabular}{|l|c|r|r|r|r|}
\hline & $\begin{array}{c}\text { Business or Industry } \\
\text { or SME/start-up }\end{array}$ & $\begin{array}{c}\text { Academic } \\
\text { or Research }\end{array}$ & $\begin{array}{c}\text { Public Sector } \\
\text { or NGO }\end{array}$ & Total & Percent \\
\hline Bulgaria & 4 & 13 & 3 & 20 & 14,2 \\
\hline Croatia & 1 & 3 & 2 & 6 & 4,3 \\
\hline Czech Republic & 0 & 14 & 12 & 26 & 18,4 \\
\hline Hungary & 14 & 19 & 12 & 45 & 31,9 \\
\hline Poland & 0 & 8 & 0 & 8 & 5,7 \\
\hline Romania & 3 & 14 & 3 & 20 & 14,2 \\
\hline Slovakia & 1 & 8 & 2 & 11 & 7,8 \\
\hline Slovenia & 1 & 1 & 3 & 5 & 3,5 \\
\hline Total & 24 & 80 & 37 & 141 & 100,0 \\
\hline
\end{tabular}

In the academic and research sector the respondents' departments perform research principally covering horizontal topics (34\%) such as economics of the supply chain $(22 \%)$, sustainability and climate change (18\%), impact assessment of life cycle analysis $(15 \%)$. Most departments study agricultural residues (18\%), conventional arable crops $(14 \%)$, energy crops $(14 \%)$, wastes of livestock/dairy sector $(11 \%)$ or forestry products, residues $(10 \%)$.

The focus of the organizations in the public sector is on agriculture $(12 \%)$, research and innovation (12\%), biomass (11\%), environmental protection (10\%), policy (10\%), sustainability $(10 \%)$, waste and management $(10 \%)$. Their activity involves mainly R\&D service and consultancy, and biomass production.

The companies involved in the biomass supply chain see bottlenecks preventing the production of advanced bio-based materials and fuels mostly at the following steps of the supply chain: conversion technology (37\%), economics of process $(29 \%)$ and standardisation and labelling (29\%). As start-up companies or R\&D/consulting services, the respondents would be able to provide solutions in order to move forward the production of advanced bio-based materials and fuels at the following step of the supply chain: conversion technology $(29 \%)$, economics of process $(25 \%)$, conversion efficiency and standardization and labelling (17\%-17\% respectively). Stakeholders of the research community would be able to provide solutions in order to move forward the production of advanced bio-based materials and fuels at the following steps of the supply chain: economics of process (20\%), impact assessment of life cycle analysis (19\%), biomass sourcing (availability) (16\%), resource efficiency of the process $(14 \%)$, demand for products $(12 \%)$. More than $2 / 3$ of these stakeholders is interested in cooperating with 
industrial partners. Respondents in the public sector would be able to provide guidance or tool in order to move forward the production of advanced bio-based materials and fuels mostly in terms of biomass sourcing. More than $2 / 3$ are not aware of any specific support instrument or tool in favour of the bioeconomy. Only references to bioeconomy specific support instruments provided by respondents are as follows: „H2020, JU BBI, FP7, RESTEP - Renewable Sustainable Energy Policy - Czech Republic - all RES applicants - www.restep.cz, Support on behalf of National Government regarding to the national strategy and special financial sources, Various calls for proposals supported by EU Structural Funds to support research and development, innovation, implementation of new technologies, demonstration plants". 80 percent of the respondents would like to work together and assist industrial and/or academic stakeholders.

In terms of what is the most beneficial for the CEE macro region in developing the bioeconomy there are both similarities and differences to be observed depending on the answers of the different stakeholder groups. On the whole, the main feedstock for bioenergy/biorefinery purposes is considered the agricultural residues which is followed by, energy crops, forestry residues, conventional arable crops, algae, forestry products, and industrial products. All three stakeholder groups think that agricultural residues could be the main feedstock for bioenergy/biorefinery purposes. On behalf of the academic and public sectors wastes of livestock/dairy sector, industrial wastes or by-products come as second and third in their ranking, the business sector, however, named - instead of the abovementioned - the forestry residues and the energy crops (Figure 4).

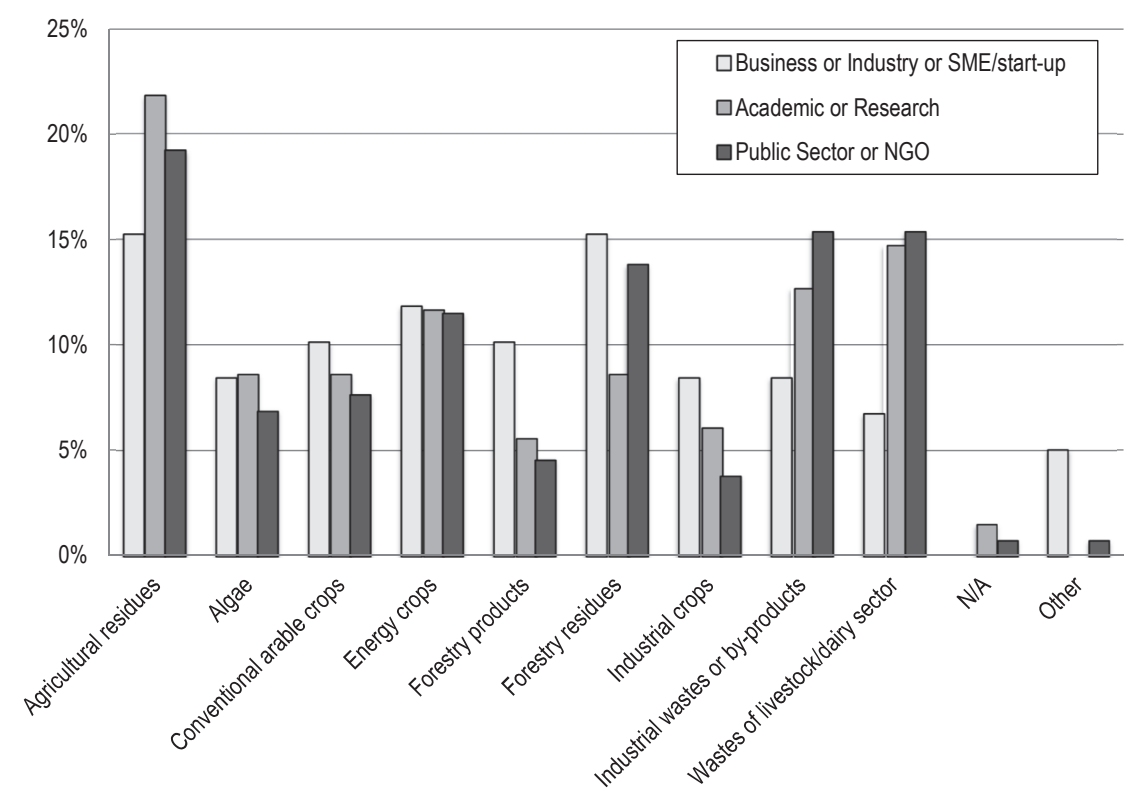

Figure 4. Main feedstocks for bioenergy/biorefinery purposes by stakeholder groups (expressed as a percentage of the total number of answers given by the individual stakeholder groups) 
The respondents pointed out some missing elements hindering the region to become competitive and listed their main opportunities, as well. As for the former half of all respondents considered the lack of financial possibilities the major missing element followed by not suitable policy framework (43\%), lack of industrial interest (36.9\%) and lack of cooperation networks (36.2\%). With regard to the latter more than half of all respondents referred to biomass potential as main opportunity, followed by creation of cooperation networks (36.9\%), exploitation of geographical location $(34,8 \%)$ and establishment of adequate research infrastructure $(34.8 \%)$.

In terms of identification of wished interventions, which are supposed to support growth in the bioeconomy, the following results were obtained. 'Counteracting the resistance to change', 'knowledge exchange' and 'resource mobilisation' were deemed the most important innovation system functions ${ }^{8}$ according to all BIOEAST countries, and within them according to V4 countries, too. The least important 'knowledge development' was addressed only by Slovakia and Romania. Among individual interventions 'providing access to financial support' played the leading role, followed by 'furthering academia to business collaboration', 'building investor confidence in bioeconomy', 'ensuring continuity of policy' and then by 'championing utilization of local resources' and 'raising public awareness of bio-based products.' (Table 4).

Table 4. Interventions presented in the survey grouped by innovation system function and the top five selected as most important by respondents from BIOEAST countries

\begin{tabular}{|c|c|c|c|c|c|c|c|c|c|}
\hline Category & Intervention & CZ & $\mathrm{PL}$ & $\mathrm{HU}$ & SK & BG & CR & RO & SI \\
\hline $\begin{array}{l}\text { I. Knowledge } \\
\text { development (R\&D) }\end{array}$ & 1. Easy access to pilot facilities & & & & $\mathrm{x}$ & & & $\mathrm{X}$ & \\
\hline \multirow{4}{*}{$\begin{array}{l}\text { Il. Knowledge } \\
\text { exchange }\end{array}$} & 1. Further academia to business collaboration & $\mathrm{x}$ & $x$ & & & $x$ & $x$ & & \\
\hline & 2. Develop regional networks or clusters & & & & & & $\mathrm{x}$ & & \\
\hline & 3. Develop international networks or clusters & & $\mathrm{x}$ & & & & & & \\
\hline & 4. Facilitate business to business collaboration & & & & $\mathrm{x}$ & & & & \\
\hline \multirow{2}{*}{$\begin{array}{l}\text { III. Guidance } \\
\text { of search }\end{array}$} & 1. Boost engagement with policy makers & & $\mathrm{x}$ & $\mathrm{x}$ & & & & & \\
\hline & 4. Advocate use of standardised LCA (Life Cycle Analysis) & & & & & & & & $\mathrm{X}$ \\
\hline \multirow{2}{*}{$\begin{array}{l}\text { IV. Market } \\
\text { formation }\end{array}$} & 1. Champion utilisation of local resources & $\mathrm{x}$ & & & $\mathrm{x}$ & & & & $\mathrm{X}$ \\
\hline & 2. Create conditions for niche markets & $\mathrm{x}$ & & & & & & & \\
\hline \multirow{2}{*}{$\begin{array}{l}\text { V. Resource } \\
\text { mobilisation }\end{array}$} & 1. Provide access to financial support & & $\mathrm{X}$ & $\mathrm{x}$ & $\mathrm{X}$ & $\mathrm{x}$ & & $\mathrm{X}$ & \\
\hline & 2. Develop a skilled workforce & & & $\mathrm{x}$ & & $\mathrm{x}$ & & & \\
\hline \multirow{4}{*}{$\begin{array}{l}\text { Vl. Resistance } \\
\text { to change } \\
\text { and legitimacy }\end{array}$} & 1. Build investor confidence in the bioeconomy & & & $\mathrm{x}$ & $\mathrm{x}$ & & $\mathrm{x}$ & $\mathrm{x}$ & \\
\hline & 2. Ensure continuity of policy & & & $\mathrm{x}$ & & $\mathrm{x}$ & $\mathrm{x}$ & & $\mathrm{X}$ \\
\hline & 3. Raise public awareness of bio-based products & $\mathrm{x}$ & & & & & $\mathrm{x}$ & & $\mathrm{X}$ \\
\hline & 4. Promote demonstration of technologies and products & $\mathrm{x}$ & & & & & & & $\mathrm{X}$ \\
\hline \multirow{3}{*}{$\begin{array}{l}\text { VII. Entrepreneurial } \\
\text { activities }\end{array}$} & 1. Focus more on industrial demands in RDI strategies & & & & & & & $\mathrm{x}$ & \\
\hline & $\begin{array}{l}\text { 3. Include business modelling and market perspective into } \\
\text { research projects }\end{array}$ & & & & & $x$ & & $\mathrm{X}$ & \\
\hline & 4. Promote open innovation approaches & & $X$ & & & & & & \\
\hline
\end{tabular}

\footnotetext{
${ }^{8}$ Innovation system functions as defined by Hekkert et al., 2007 („The goal of any innovation system is to generate and diffuse innovations which lead to technological change." Hodgson et al., 2016).
} 
By comparing this result (Table 5) with that gained by Hodgson and his colleagues who analysed France, Germany, Italy, Spain and Great-Britain, it is obvious that the most important innovation function for these countries is also 'counteracting the resistance to change', followed by 'guidance of the search' and 'resource mobilisation'. There is, however, a difference in the ranking of individual interventions in these old Member States compared to BIOEAST countries. Their priority is 'building investor confidence in bioeconomy' followed by 4 equally weighted interventions: 'providing access to financial support', 'ensuring continuity of policy', 'stimulating industrial symbiosis' and 'promoting demonstration of technologies and products' (Hodgson, 2016).

Table 5. Ranking of interventions grouped by innovation system function based on their perceived importance in certain old Member States and in BIOEAST countries

\begin{tabular}{|c|c|c|c|}
\hline Category & Intervention & \begin{tabular}{|c|} 
FR, DE, IT, \\
$\mathrm{ES}, \mathrm{UK}^{*}$ \\
\end{tabular} & $\begin{array}{l}\text { BIOEAST } \\
\text { countries }\end{array}$ \\
\hline \multirow{3}{*}{$\begin{array}{l}\text { I. Knowledge } \\
\text { development } \\
\text { (R\&D) }\end{array}$} & 1. Easy access to pilot facilities & & 4. \\
\hline & 2. Establish knowledge of best conversion routes for biomass type & 3. & \\
\hline & 3. Identify and address knowledge gaps & 4. & \\
\hline \multirow{4}{*}{$\begin{array}{l}\text { II. Knowledge } \\
\text { exchange }\end{array}$} & 1. Further academia to business collaboration & 3. & 2. \\
\hline & 2. Develop regional networks or clusters & & 5. \\
\hline & 3. Develop international networks or clusters & & 5. \\
\hline & 4. Facilitate business to business collaboration & & 5. \\
\hline \multirow{3}{*}{$\begin{array}{l}\text { III. Guidance } \\
\text { of search }\end{array}$} & 1. Boost engagement with policy makers & 4. & 4. \\
\hline & 2. Stimulate industrial symbiosis - sharing of resources & 2. & \\
\hline & 4. Advocate use of standardised LCA (Life Cycle Analysis) & & 5. \\
\hline \multirow{2}{*}{$\begin{array}{l}\text { IV. Market } \\
\text { formation }\end{array}$} & 1. Champion utilisation of local resources & & 3. \\
\hline & 2. Create conditions for niche markets & & 5. \\
\hline \multirow{2}{*}{$\begin{array}{l}\text { V. Resource } \\
\text { mobilisation }\end{array}$} & 1. Provide access to financial support & 2. & 1. \\
\hline & 2. Develop a skilled workforce & 4. & 4. \\
\hline \multirow{4}{*}{$\begin{array}{l}\text { VI. Resistance } \\
\text { to change } \\
\text { and legitimacy }\end{array}$} & 1. Build investor confidence in the bioeconomy & 1. & 2. \\
\hline & 2. Ensure continuity of policy & 2. & 2. \\
\hline & 3. Raise public awareness of bio-based products & 4. & 3. \\
\hline & 4. Promote demonstration of technologies and products & 2. & 4. \\
\hline \multirow{3}{*}{$\begin{array}{l}\text { VII. Entrepreneurial } \\
\text { activities }^{\star *}\end{array}$} & 1. Focus more on industrial demands in RDI strategies & & 5. \\
\hline & 2. Develop start-up incubation programs with bioeconomy focus & & 4. \\
\hline & $\begin{array}{l}\text { 3. Include business modelling and market perspective into research } \\
\text { projects }\end{array}$ & & 5. \\
\hline
\end{tabular}

Note: * based on Hodgson et al., 2016:512; ** VII. Entrepreneurial activities were not included in the study by Hodgson et al.

Source: Hodgson et al., 2016 and own research

The importance of individual interventions in the BIOEAST countries seems to differ among the stakeholder groups, as it is visible in Table 6 . 
Table 6. Interventions presented in the survey grouped by innovation system function and the top five selected as most important by respondents of the three stakeholder groups

\begin{tabular}{|l|l|c|c|c|}
\hline \multicolumn{1}{|c|}{ Category } & \multicolumn{1}{|c|}{ Intervention } & $\begin{array}{c}\text { Business } \\
\text { or Industry } \\
\text { or SME/start-up }\end{array}$ & $\begin{array}{c}\text { Academic } \\
\text { or Research }\end{array}$ & $\begin{array}{c}\text { Public } \\
\text { Sector } \\
\text { or NGO }\end{array}$ \\
\hline $\begin{array}{l}\text { II. Knowledge } \\
\text { exchange }\end{array}$ & 1. Further academia to business collaboration & & $\mathrm{x}$ & $\mathrm{x}$ \\
\hline $\begin{array}{l}\text { III. Guidance } \\
\text { of search }\end{array}$ & 1. Boost engagement with policy makers & $\mathrm{x}$ & $\mathrm{x}$ \\
\hline \multirow{2}{*}{$\begin{array}{l}\text { IV. Market } \\
\text { formation }\end{array}$} & 1. Champion utilisation of local resources & & & $\mathrm{x}$ \\
\cline { 2 - 5 } & $\begin{array}{l}\text { 2. Create conditions for niche markets } \\
\text { 3. Build stakeholder consensus on how best } \\
\text { to develop bioeconomy }\end{array}$ & & $\mathrm{x}$ & \\
\hline $\begin{array}{l}\text { V. Resource } \\
\text { mobilisation }\end{array}$ & 1. Provide access to financial support & $\mathrm{x}$ & \\
\hline $\begin{array}{l}\text { VI. Resistance } \\
\text { to change } \\
\text { and legitimacy }\end{array}$ & 1. Build investor confidence in the bioeconomy & 2. Ensure continuity of policy & $\mathrm{x}$ & $\mathrm{x}$ \\
\cline { 2 - 5 } $\begin{array}{l}\text { 3. Raise public awareness of bio-based products } \\
\text { VII. Entrepreneurial } \\
\text { activities }\end{array}$ & $\begin{array}{l}\text { 1. Focus more on industrial demands in RDI } \\
\text { strategies }\end{array}$ & $\mathrm{x}$ & $\mathrm{x}$ & \\
\hline
\end{tabular}

The interventions 'furthering academia to business collaboration' and 'building investor confidence in bioeconomy' are equally important for the Academic or Research and the Public sector. The interventions 'boosting engagement with policy makers' and 'ensuring continuity of policy' are equally weighted by the Business and the Public sector. The intervention 'providing access to financial support was highlighted by the Business and the Academic sector. The remaining interventions were selected as most important only by one of these stakeholder groups.

There are only a few interventions where the difference between stakeholder groups seems to be rather considerable (Figure 5). In these cases - 'improving access to pilot facilities', 'furthering academia to business collaboration', 'developing regional networks and clusters', 'championing utilization of local resources', 'developing start-up incubation programs with bioeconomy focus' and 'promoting open innovation approaches' - the perceived importance is higher for the academia than for the business sector and it is the highest in the public sector.

The comparison of BIOEAST countries show that the difference in the perceived importance of intervention is not significant in most cases. (Figure 6). 


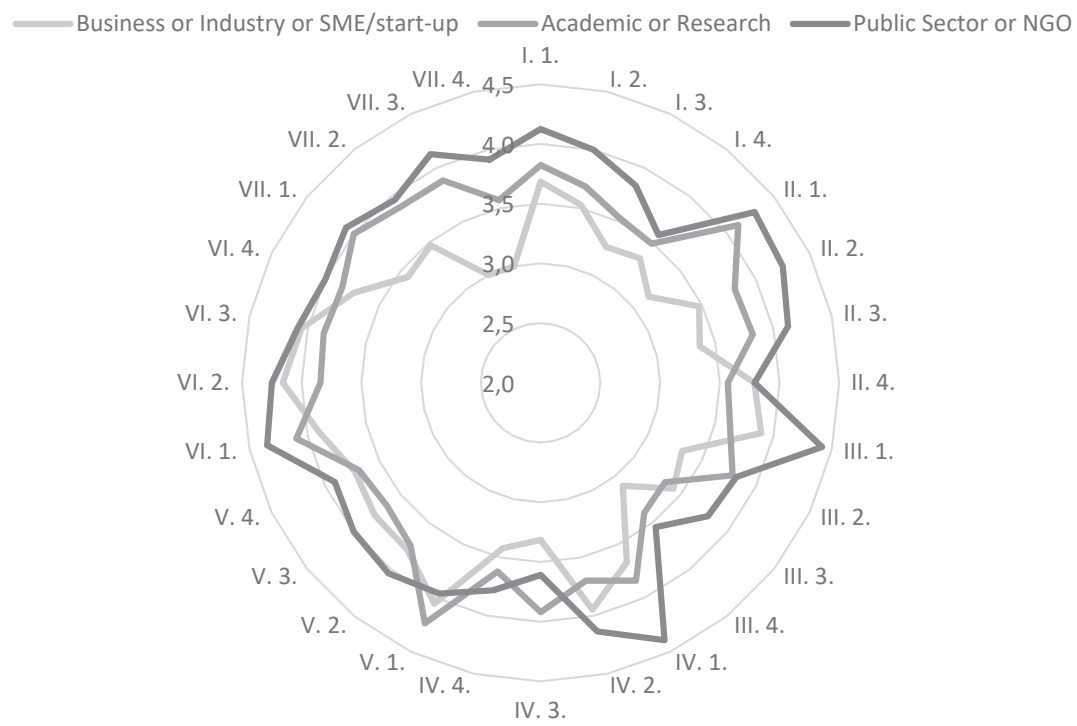

Figure 5. Difference in perceived importance of interventions among stakeholder groups (1=Least beneficial $-5=$ Most beneficial)

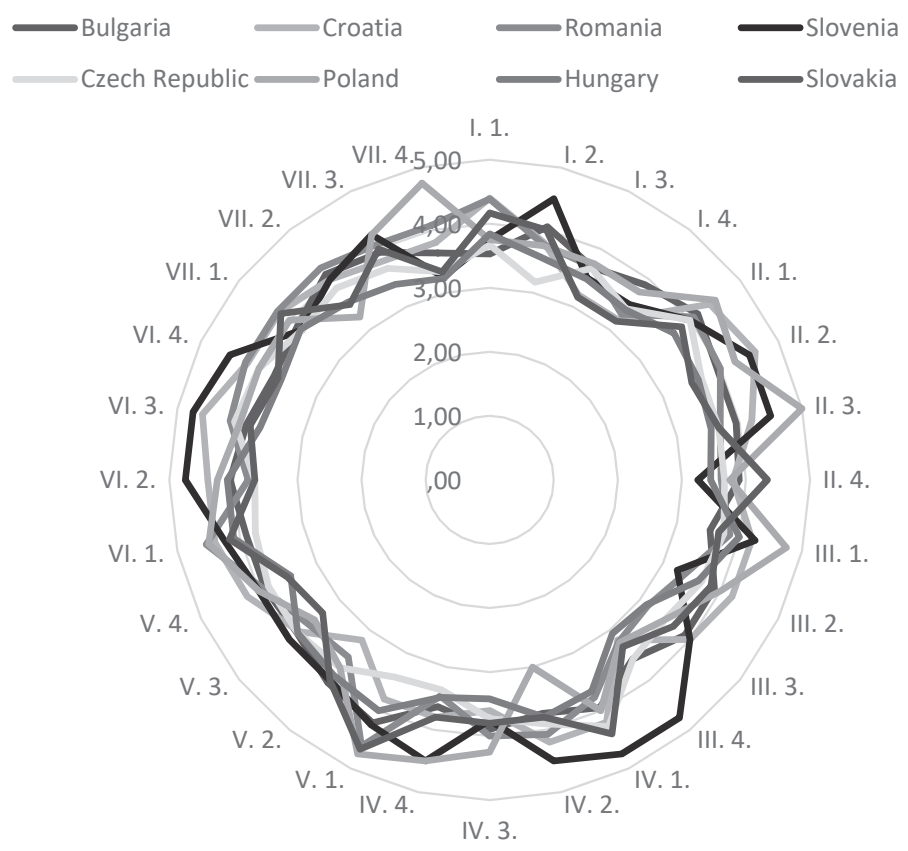

Figure 6. Difference in perceived importance of interventions among BIOEAST countries (1=Least beneficial $-5=$ Most beneficial) 


\section{Discussion}

The information gained from the BIOEAST survey firmly confirms on the one hand the low level of bioeconomy maturity - i.e. their potential in terms of employment, creation of value added or apparent labour productivity etc. is not fully exploited ${ }^{9}-$ and on the other hand the strong willingness of the different stakeholder groups to cooperate. As for the latter an effective regional cooperation - based on a faster development and adaption of scientific and technological advances in the primary sectors (agriculture, aquaculture, forestry) - requires well-established networks, the development of capacities, skills, clear identification of problems and developing strategies which can be put efficiently into operation. Further suggestive results - in terms of what are (1) the missing elements hindering competitiveness in the bioeconomy, (2) the opportunities to raise competitiveness, (3) most important innovation system functions, (4) major bottleneck in the supply chain - which at the same time verify and strengthen the objectives of the BIOEAST Initiative are listed in Figure 7 where it is indicated which objectives are supported by them. The objectives are as follows:

- "Objective 1: Initiate cooperation and the development of knowledge-based policies: establish a multi-stakeholder network and cluster at European level to facilitate joint actions, backed up by a renewed commitment to closer cooperation at both the political and operational levels through close personal contacts and communication between the countries concerned at the operational level;

- Objective 2: Identify common challenges and validate common research topics: map specific challenges for a Strategic Research and Innovation Agenda and foster innovative multidisciplinary research and cooperation activities. These should address the relevant common CEE challenges by means of common work carried out by experts as a follow up to the Visegrad4 +3 Common Declaration as a starting point for the discussion;

- Objective 3: Initiate strategies: create a cross-sectorial approach for the development of a national circular and bioeconomy strategy;

- Objective 4: Provide an evidence base: establish data-driven support for implementation of policies through the creation of an interoperable, fully integrated observing and forecasting system. This would promote continuous, long-term observation based on open data structures to guarantee easy access;

- Objective 5: Improve skills: train a new generation of dedicated multi-stakeholder actors;

- Objective 6: Initiate development of synergies: promote regional, national, EU and international funding opportunities to develop innovative technologies, methodologies and approaches. The purpose would be to boost the sustainable and circular

\footnotetext{
${ }^{9}$ See Ronzon et al., 2017: 48.
} 
economic growth of the European bioeconomy sectors and the conservation and upgrading of the regional environment, resources and cultural heritage;

- Objective 7: Increase visibility: draw attention to specific challenges and research potential of the macro-region, through involving society and promoting public awareness". (BIOEAST, 2018)

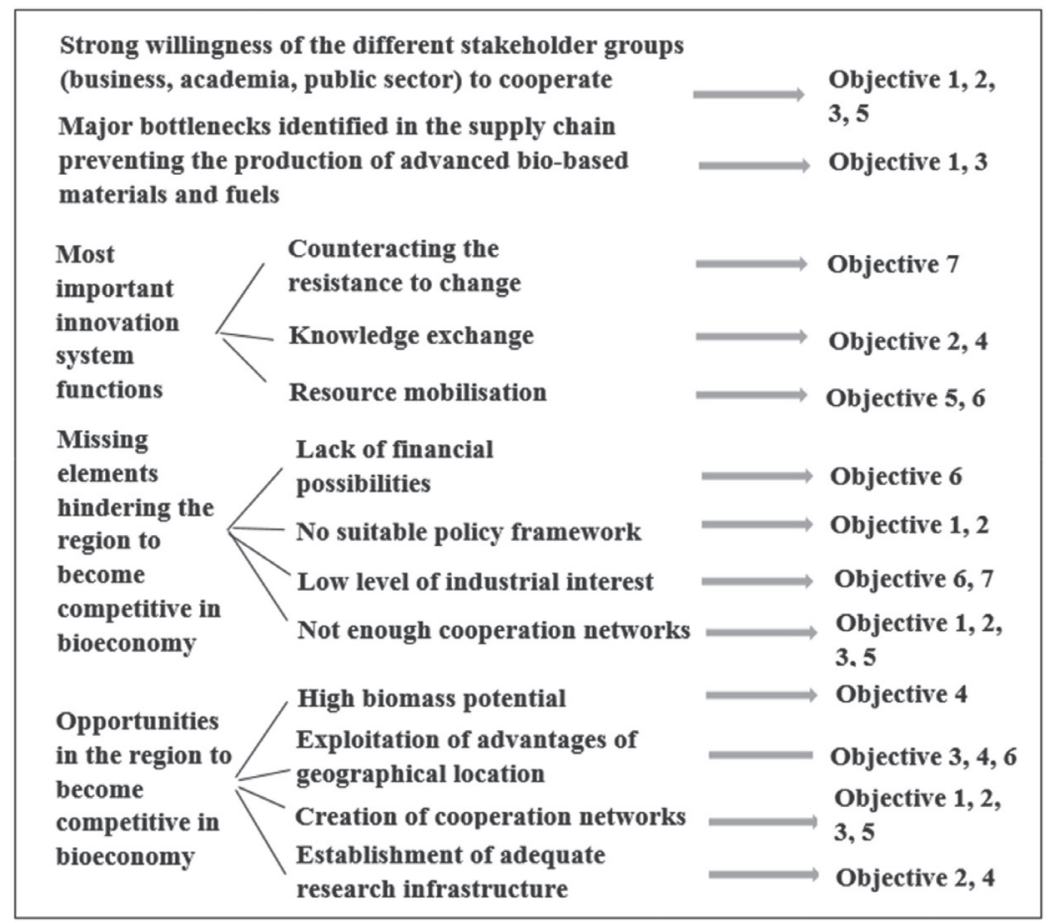

Figure 7. Findings of the BIOEAST Survey verifying the Objectives of the BIOEAST Initiative

\section{Conclusion}

The size of the sample of the research is definitely small and the lack of representativeness lead to further questions. Despite methodological difficulties we can state even at this first stage of research and following in Hodgson and his colleagues' footsteps- that innovation system frameworks were proven to be able to provide a better understanding of the drivers of bioeconomy, a thought provoking assessment of perceptions on policy interventions, and useful implications for policymakers both by counties and by academic, business and policy stakeholder groups. Thus, this kind of research ought to be carried out on a regular basis. Further results and implications could support our society in embracing sustainable bioeconomy and contribute to regional collaboration of triple-helix stakeholders. 


\section{References}

Aguilar, A., Wohlgemuth, R., Twardowski, T. (2018). Perspectives on bioeconomy. New Biotechnology 40, 181-184. https://doi.org/10.1016/j.nbt.2017.06.012

Bell, J., Paula, L., Dodd, T., Németh, Sz., Nanou, C., Mega, V., Campos, P. (2018). EU ambition to build the world's leading bioeconomy. Uncertain times demand innovative and sustainable solutions. New Biotechnology 40, 25-30: https://doi.org/10.1016/j.nbt.2017.06.010

BIOEAST (2018). BIOEAST Vision Paper. BIOEAST-Central and Eastern European Initiative for Knowledge-Based Agriculture, Aquaculture and Forestry in the Bioeconomy. 2018, p. 15. http://www.bioeast.eu/article/bioeastvisionpaper23022018 (accessed on 28 May 2018).

Bugge, M.M., Hansen, T., Klitkou, A. (2016). What Is the Bioeconomy? A Review of the Literature. Sustainability, 8, 691: https://doi.org/10.3390/su8070691

D'Amato, D., Droste, N., Allen, B., Kettunen, M. Lähtinen K., Korhonen, J., Leskinen, P., Matthies, B.D., Toppinen, A. (2017). Green, circular, bio economy: A comparative analysis of sustainability avenues. Journal of Cleaner Production 168, 716-734: https://doi.org/10.1016/j. jclepro.2017.09.053

Dupont-Inglis, J., Borg, A. (2018). Destination bioeconomy - The path towards a smarter, more sustainable future. New Biotechnology 40, 140-143. https://doi.org/10.1016/j.nbt.2017.05.010

Efken, J., Dirksmeyer, W., Kreins, P., Knecht, M. (2016). Measuring the importance of the bioeconomy in Germany: Concept and illustration. NJAS - Wageningen Journal of Life Sciences 77 (2016) 9-17. https://doi.org/10.1016/..njas.2016.03.008

Ellen Macarthur Foundation: Circular Economy System Diagram, available at: https://www.ellenmacarthurfoundation.org/circular-economy/interactive-diagram (accessed 10 May 2018)

European Commission (EC) (2012). Innovating for Sustainable Growth: A Bioeconomy for Europe; COM(2012) 60 Final; European Commission: Brussels, Belgium,; p. 9. http://ec.europa. eu/research/bioeconomy/pdf/official-strategy_en.pdf (accessed on 28 May 2018).

European Commission: Circular economy, available at: http://ec.europa.eu/environment/circulareconomy/index_en.htm (accessed 10 May 2018).

European Commission (EC) (2013). A bioeconomy strategy for Europe. Publications Office of the European Union, Luxembourg. https://doi.org/10.2777/17708

European Commission (EC) (2014). Where next for the European bioeconomy? The latest thinking from the European Bioeconomy Panel and the Standing Committee on Agricultural Research Strategic Working Group (SCAR). Publications Office of the European Union, Luxembourg. https://doi.org/10.2777/95624

European Commission (EC) (2017). Review of the EU bioeconomy strategy and its action plan Expert group report - Study. Publications Office of the European Union, Luxembourg. https:// doi.org/10.2777/149467

Geissdoerfer, M., Savaget, P., Bocken, N. M. P.; Hultink, E. J. (2017). The Circular Economy - A new sustainability paradigm? Journal of Cleaner Production, 143, 757-768. https://doi. org/10.1016/j.jclepro.2016.12.048 
Filho, W. L., Pociovălișteanu, D. M., Borges de Brito, P. R., Borges de Lima, I.(eds) (2018). Towards a Sustainable Bioeconomy: Principles, Challenges and Perspectives, Springer $1^{\text {st }}$ edition Golden, J.S., Handfield, R., Pascual-Gonzalez, J., Agsten, B., Brennan, T., Khan, L., True, E. (2018). Indicators of the U.S. Biobased Economy. U.S. Department of Agriculture, Office of Energy Policy and New Uses, Office of the Chief Economist (accessed 28 May 2018)

Hekkert MP, Suurs RAA, Negro SO, Kuhlmann S and Smits REHM (2007). Functions of innovation systems: A new approach for analysing technological change. Technological Forecasting and Social Change 74(4). 413-432

Hodgson, E., Ruiz-Molina, M-E., Marazza, D., Pogrebnyakova, E., Burns, C., Higson, A., Rehberger, M., Hiete, M., Gyalai-Korpos, M., Di Lucia, L., Noël, Y., Woods, J., Gallagher, J. (2016). Horizon scanning the European bio-based economy: a novel approach to the identification of barriers and key policy interventions from stakeholders in multiple sectors and regions Biofuels, Bioproducts and Biorefining. 10(5). 508-522. https://doi.org/10.1002/bbb.1665

Kirchherr, J., Reike, D., Hekkert, M. (2017). Conceptualizing the circular economy: An analysis of 114 definitions. Resources, Conservation and Recycling 127, 221-232. https://doi. org/10.1016/j.resconrec.2017.09.005

Korhonen, J., Honkasalo, A., Seppälä, J. (2018). Circular Economy: The Concept and its Limitations. Ecological Economics 143, 37-46. https://doi.org/10.1016/j.ecolecon.2017.06.041

Kovacs, B., Mathijs, E., Brunori, G., Carus, M., Griffon, M., Last, L., Gill, M., Koljonen, T., Lehoczky, É., Olesen, I., Potthast, A. (2015). Sustainable Agriculture, Forestry and Fisheries in the Bioeconomy -A Challenge for Europe. 10.2777/179843.

Lewandowski, I. (ed., author) (2017): Bioeconomy: Shaping the transition to a sustainable, biobased economy, (1 ${ }^{\text {st }}$ edition) Springer).

McCarthy, A., Dellink, R., Bibas, R. (2018). The Macroeconomics of the Circular Economy Transition: A Critical Review of Modelling Approaches, OECD Environment Working Papers, 130, OECD Publishing, Paris, http://dx.doi.org/10.1787/af983f9a-en

OECD (2009). The Bioeconomy to 2030: Designing a Policy Agenda, OECD Publishing, Paris, http://dx.doi.org/10.1787/9789264056886-en

OECD (2018). The bioeconomy concept: Then and now, in Meeting Policy Challenges for a Sustainable Bioeconomy, OECD Publishing, Paris, http://dx.doi.org/10.1787/9789264292345-4-en

Patermann, C., Aguilar, A. (2018). The origins of the bioeconomy in the European Union. New Biotechnology 40, 20-24. https://doi.org/10.1016/.nbt.2017.04.002

Pavone, V., Goven, J. (2017). Bioeconomies: Life, Technology, and Capital in the 21st Century (1 ${ }^{\text {st }}$ editon), Palgrave Macmillan.

Philp, J. (2018). The bioeconomy, the challenge of the century for policy makers. New Biotechnology 40 (2018) 11-19. https://doi.org/10.1016/j.nbt.2017.04.004

Ritzén, S., Sandström, G. Ö. (2017). Barriers to the Circular Economy - integration of perspectives and domains. Procedia CIRP 64, 7-12. 
Ronzon, T., Piotrowski, S., M'Barek, R., Carus, M. (2017). A systematic approach to understanding and quantifying the EU's bioeconomy Bio-based and Applied Economics 6(1), 1-17. http:// dx.doi.org/10.13128/BAE-20567

Ronzon, T.; M'Barek, R. (2018). Socioeconomic Indicators to Monitor the EU's Bioeconomy in Transition. Sustainability 10. 6 https://doi.org/10.3390/su10061745

Scarlat, N., Dallemand, J., Monforti-Ferrario, F., Nita, V. (2015). The role of biomass and bioenergy in a future bioeconomy: Policies and facts. Environmental Development 15, 3-34. https:// doi.org/10.1016/j.envdev.2015.03.006

Schütte, G. (2018). What kind of innovation policy does the bioeconomy need? New Biotechnology 40, 82-86. https://doi.org/10.1016/j.nbt.2017.04.003

Spatial Foresight, SWECO, ÖIR, t33, Nordregio, Berman Group, Infyde (2017). Bioeconomy development in EU regions. Mapping of EU Member States'/regions' Research and Innovation plans \& Strategies for Smart Specialisation (RIS3) on Bioeconomy for 2014-020.

Thorenz, A., Wietschel, L., Stindt, D., Tuma, A. (2018). Assessment of agroforestry residue potentials for the bioeconomy in the European Union. Journal of Cleaner Production 176, 348359. https://doi.org/10.1016/j.jclepro.2017.12.143

Wozniak,E., Twardowski, T. (2018). The bioeconomy in Poland within the context of the European Union. New Biotechnology 40 (2018) 96-102. https://doi.org/10.1016/..nbt.2017.06.003

\section{Annex 1: People employed, value added, turnover in the bioeconomy}

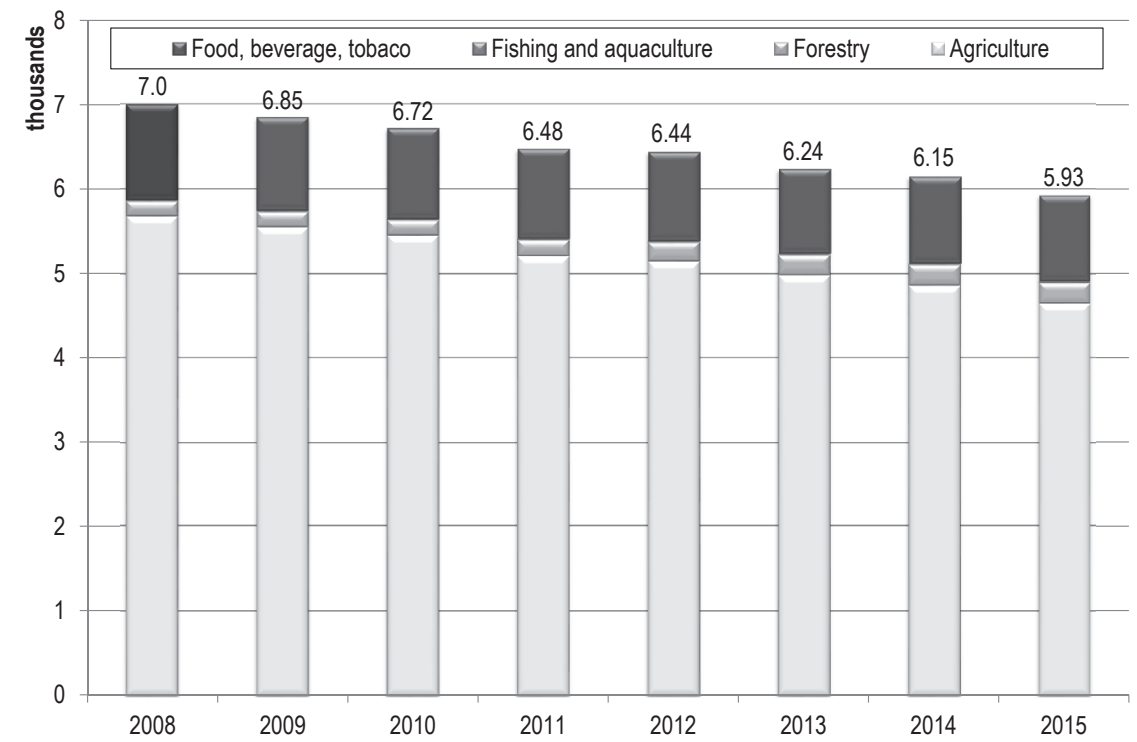

Figure 1. Development of the number of people employed by selected sectors (total number of people employed in the BIOEAST countries)

Source: own composition based on JRC Bioeconomics dataset. 


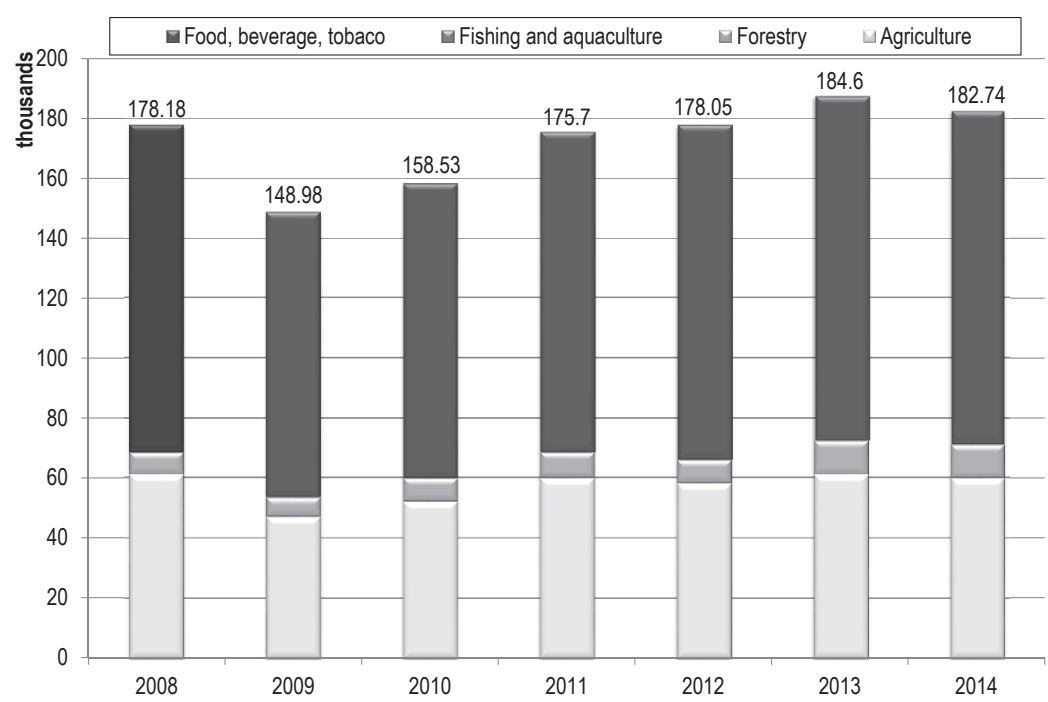

Figure 2. Development of sectorial turnover in the bioeconomy (million EUR) by selected sectors in the BIOEAST countries

Source: own composition based on JRC Bioeconomics dataset

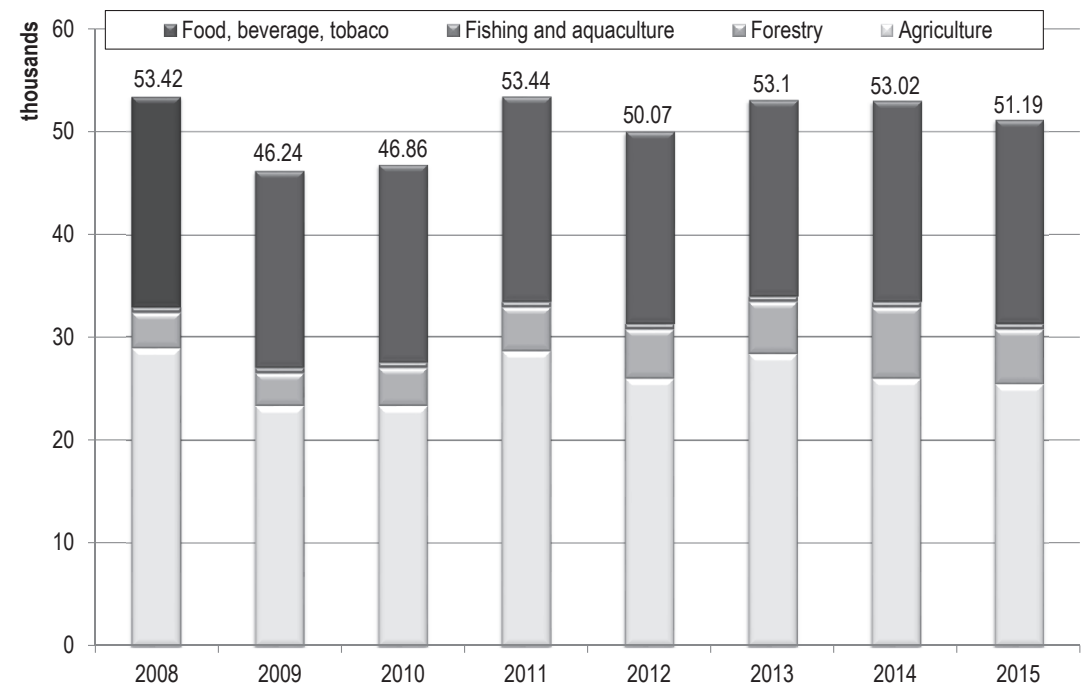

Figure 3. Development of sectorial value added in the bioeconomy (million EUR) by selected sectors in the BIOEAST countries

Source: own composition based on JRC Bioeconomics dataset. 


\section{Annex 2: Development of the number of people employed by selected sectors (total number)/ turnover (million EUR) and value added (million EUR) in the bioeconomy $(2008,2012,2015)$}

\begin{tabular}{|c|c|c|c|c|c|c|c|c|c|c|}
\hline & & & BG & HR & $\mathrm{CZ}$ & $\mathrm{HU}$ & PL & RO & SK & SL \\
\hline \multirow{12}{*}{ 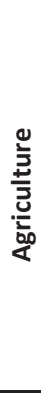 } & \multicolumn{10}{|c|}{ People employed } \\
\hline & 2008 & & 224600 & 207600 & 125000 & 150500 & 2139700 & 2635700 & 70700 & 80100 \\
\hline & 2012 & & 168100 & 172700 & 115100 & 173200 & 1878400 & 2498100 & 55100 & 73200 \\
\hline & 2015 & & 177300 & 127700 & 114200 & 178800 & 1768600 & 2129600 & 57900 & 60100 \\
\hline & \multicolumn{10}{|c|}{ Turnover } \\
\hline & 2008 & & 3865 & 2946 & 4607 & 7219 & 21167 & 16683 & 2147 & 1147 \\
\hline & 2012 & & 3891 & 2607 & 4640 & 6977 & 22578 & 13001 & 2155 & 1131 \\
\hline & 2015 & & 3667 & 1935 & 4445 & 7442 & 21709 & 13822 & 1894 & 1257 \\
\hline & \multicolumn{10}{|c|}{ Value Added } \\
\hline & 2008 & & 2020 & 1715 & 2291 & 3427 & 8216 & 8731 & 1917 & 448 \\
\hline & 2012 & & 1724 & 1330 & 2658 & 3600 & 9154 & 5668 & 1783 & 443 \\
\hline & 2015 & & 1642 & 1220 & 2657 & 3879 & 8064 & 5910 & 1907 & 578 \\
\hline \multirow{12}{*}{ 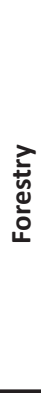 } & \multicolumn{10}{|c|}{ People employed } \\
\hline & 2008 & & 25000 & 13000 & 30900 & 12600 & 60500 & 49100 & 25400 & 4500 \\
\hline & 2012 & & 19300 & 14400 & 32000 & 19000 & 73600 & 56600 & 20300 & 3400 \\
\hline & 2015 & & 28600 & 15100 & 30100 & 25300 & 72700 & 51600 & 18400 & 4000 \\
\hline & \multicolumn{10}{|c|}{ Turnover } \\
\hline & 2008 & & 408 & 331 & 1884 & 407 & 3947 & 760 & 679 & 279 \\
\hline & 2012 & & 572 & 331 & 2324 & 452 & 2602 & 1355 & 734 & 366 \\
\hline & 2015 & & 741 & 303 & 2209 & 488 & 5241 & 1930 & 786 & 402 \\
\hline & \multicolumn{10}{|c|}{ Value Added } \\
\hline & 2008 & & 157 & 222 & 812 & 194 & 1023 & 455 & 522 & 178 \\
\hline & 2012 & & 176 & 211 & 1110 & 210 & 1160 & 530 & 566 & 199 \\
\hline & 2015 & & 210 & 212 & 1073 & 214 & 1328 & 647 & 728 & 203 \\
\hline \multirow{12}{*}{ 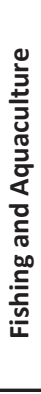 } & \multicolumn{10}{|c|}{ People employed } \\
\hline & 2008 & & 1921 & 6782 & 0 & 0 & 8609 & 3544 & 0 & 138 \\
\hline & 2012 & & 1995 & 6779 & 0 & 0 & 8184 & 3439 & 0 & 141 \\
\hline & 2015 & & 2652 & 7298 & 0 & 0 & 10255 & 2894 & 0 & 139 \\
\hline & \multicolumn{10}{|c|}{ Turnover } \\
\hline & 2008 & 13 & & 126 & 0 & 0 & 111 & 15 & 0 & 3 \\
\hline & 2012 & 15 & & 125 & 0 & 0 & 164 & 19 & 0 & 2 \\
\hline & 2015 & 22 & & 134 & 0 & 0 & 138 & 23 & 0 & 2 \\
\hline & \multicolumn{10}{|c|}{ Value Added } \\
\hline & 2008 & & 10 & 100 & 18 & 15 & 47 & 12 & 5 & 4 \\
\hline & 2012 & & 13 & 128 & 26 & 16 & 60 & 34 & 2 & 4 \\
\hline & 2015 & & 21 & 137 & 23 & 15 & 80 & 152 & 37 & 5 \\
\hline \multirow{9}{*}{ 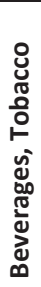 } & \multicolumn{10}{|c|}{ People employed } \\
\hline & 2008 & & 110696 & 68373 & 125239 & 111303 & 445337 & 208537 & 40029 & 17845 \\
\hline & 2012 & & 97346 & 65127 & 115725 & 104090 & 422246 & 187037 & 40003 & 15899 \\
\hline & 2015 & & 98611 & 61722 & 116887 & 107914 & 423197 & 182514 & 39488 & 16468 \\
\hline & \multicolumn{10}{|c|}{ Turnover } \\
\hline & 2008 & & 5209 & 5700 & 15221 & 12013 & 52584 & 12382 & 4074 & 2259 \\
\hline & 2012 & & 5560 & 5597 & 14331 & 11985 & 56903 & 11203 & 4491 & 2148 \\
\hline & 2015 & & 6077 & 5481 & 13407 & 11979 & 58512 & 12257 & 4227 & 2212 \\
\hline & \multicolumn{10}{|c|}{ Value Added } \\
\hline 뭉 & 2008 & & 862 & 1374 & 2843 & 2058 & 10070 & 2566 & 636 & 469 \\
\hline 누 & 2012 & & 949 & 1259 & 2729 & 1781 & 9332 & 2001 & 772 & 446 \\
\hline & 2015 & & 1059 & 1224 & 2659 & 2087 & 10291 & 1661 & 756 & 506 \\
\hline
\end{tabular}

Note: ' $O$ ' means there is no available data in the dataset.

Source: own composition based on JRC Bioeconomics dataset. https://datam.jrc.ec.europa.eu/datam/perm/od/ jrc-datam-biomass-estimates 